\title{
VYTAUTAS KAVOLIS - METODOLOGINIO ANARCHIZMO ATSTOVAS?
}

\author{
Alvydas Noreika \\ Kultūros, filosofijos ir meno institutas, Dabartinès filosofijos skyrius, Saltoniškių g. 58, LT-08105 Vilnius, Lietuva. \\ El. paštas: alvydas.noreika@komo.lt
}

Straipsnyje analizuojama žymaus lietuvių socialinio teoretiko Vytauto Kavolio civilizaciju tyrimų metodologija. Siekiama atsakyti j klausima, ar V. Kavolis užima metodologinio anarchizmo pozicija, pagal kuriq „viskas tinka“" ar vis dellto jo civilizaciju tyrimu metodologija, nepaisant savo tarpdisciplininio ir multimetodologinio pobūdžio, turi ją koordinuojantị branduolį? Straipsnio autorius gina teiginį, kad Vytautas Kavolis nèra metodologinio anarchizmo atstovas. Jis nuosekliai plètoja civilizaciju tyrimu metodologija, kurios branduoli sudaro civilizacijų analizès metodas. Esant tarpdisciplininiam požiūriui, konkrečias disciplinas ir teorinius požiūrius papildomai koordinuoja tyrimu objektas (civilizacija).

Reikšminiai žodžiai: civilizacija, civilizacijų analizè, civilizacijų analizès metodas, lyginamasis požiūris, tarpdisciplininis požiūris.

\section{İvadas}

$\mathrm{XX}$ a. II pusèje prasidèję ir iki šiol tebevykstantys kultūriniai procesai, kaip antai antroji globalizacijos banga, Vakarų visuomenių kultūros fragmentacija, vèlyvosios modernybès tribalizmas, ìvairiausių fundamentalizmų atgimimas, iš tyrinètojų reikalauja naujų teorinių bei metodologinių sprendimų. Būtina surasti tokias priemones, kurios leistų adekvačiai konceptualizuoti ir pažinti dabartinę kultūrinę tikrovę. Šiuo požiūriu ypač reikšmingi žymaus lietuvių socialinio teoretiko Vytauto Kavolio civilizacijų studijų darbai.

Savo konkrečiuose civilizaciniuose tyrinèjimuose V. Kavolis novatoriškai sieja skirtingas disciplinas, metodus ir skirtingoms teorinems pozicijoms atstovaujančius autorius. Tačiau kiekvienu konkrečiu atveju jis nepaaiškina, kokiu pagrindu remdamasis tai daro. Tai galioja net ir tuo atveju, kai V. Kavolis kritiškai vertina įvairius metodus bei teorines pozicijas. Todèl kyla klausimas, ar V. Kavolis užima metodologinio anarchizmo poziciją, pagal kurią „viskas tinka“, ar vis dèlto jo civilizacijų tyrimų metodologija, nepaisant savo tarpdisciplininio ir multimetodologinio pobūdžio, turi ją koordinuojantị branduolį?

\section{Civilizacijų analizès metodologija}

Siekiant atsakyti ị čia suformuluotą klausimą ypač reikšmingas yra kartu su B. Nelsonu parašytas programinis straipsnis Civilizacinis analitinis požiūris i lyginamąsias studijas (Nelson, Kavolis 1973). Šiame straipsnyje B. Nelsonas ir V. Kavolis glaustai pateikia savo pranešime Lyginamoji ir civilizacine perspektyvos socialiniuose ir humanitariniuose moksluose ${ }^{1}$ išdèstytus pagrindinius metodologinius civilizacijų tyrimų principus, kurie taps viso ju-

1 Pranešimas skaitytas $1972 \mathrm{~m}$. gruodžio 19 d. Vašingtone vykusiame metiniame Tarptautinès lyginamujy civilizaciju studiju draugijos susirinkime. 
dejjimo - Tarptautinès lyginamujų civilizacijų studijų draugijos - metodologinèmis gairèmis. Straipsnyje Civilizacinis analitinis požiūris ị lyginamąsias studijas (Nelson, Kavolis 1973) išskirtinis dèmesys skiriamas lyginamajam požiūriui. B. Nelsonas ir V. Kavolis išskiria aštuonias pagrindines lyginamųjų tyrimų perspektyvas, iš kurių keturios yra susiję su nacionalinių visuomenių ir kultūrų tyrimais, o kitos keturios - su civilizacijų tyrimais: 1) lyginamoji visuomenių kaip socialinių sistemų analizè; 2) lyginamoji sisteminė analogiškų visuomeninių institucijų analizė; 3) kultūros struktūrų (cultural patterns) ar kompleksų „kultūra ir asmenybe்“ kaip visumų lyginamieji tyrimai; 4) tarpkultūriniai konkrečių kultūros procesų ir jų pasekmių tyrimai; 5) tiesioginiai lyginamieji civilizacijų kaip visumų tyrimai; 6) lyginamoji visų civilizacijų apžvalga siekiant nustatyti negrịžtamas vystymosi kryptis; 7) lyginamoji institucijų ir simbolinių konstrukcijų analizè, atsižvelgiant i jų socialinị kontekstą; 8) lyginamieji konkrečių civilizacijų santykių ir susidūrimų tyrimai. Paskutinès dvi perspektyvos nurodomos kaip pačios perspektyviausios. Straipsnio autorių ịsitikinimu, lyginamoji konkrečių sociokultūrinių konfigūracijų ir civilizacijų santykių analizė leidžia išvengti penktajai ir šeštajai perspektyvai būdingų skubotų apibendrinimų bei schematiškumo. Jų atveju „konkrečios situacijos, institucijos ar probleminès sritys nagrinėjamos su atviru dèmesiu ir pagarba besiskiriančių reiškinių unikalumui ir savitumui“" (Nelson 1974: 138).

Išskyrę dvi prioritetines lyginamųjų tyrimų kryptis, B. Nelsonas ir V. Kavolis išdèsto savo požiūrị ị tai, kaip turi būti atliekama lyginamoji

2 Pastaruoju metu saqvoka civilizaciju analizè yra plačiai paplitusi ir del to igijusi papildomu prasmių. Dažnai civilizaciju analize ịvardijamas bet koks civilizaciju tyrimas; kartu bet kuris civilizacijų tyrinetojas tampa civilizaciju analitiku. Čia savoka civilizacijų analizè vartojama pirmine prasme. Ji žymi ne apskritai civilizaciju tyrimus, bet konkrečia civilizaciju sociologijos perspektyva, kuriai atstovauja B. Nelsonas, V. Kavolis, R. Robertsonas, B. Holzneris ir kiti su Tarptautine lyginamujy civilizaciju studiju draugija susije civilizaciju tyrinetojai. sociokultūrinių struktūrų ir civilizacijų santykių analizè. Taip civilizacijų sociologijoje gimsta nauja teorinè perspektyva - civilizacijų analize $\dot{e}^{2}$. B. Nelsonas ir V. Kavolis nurodo penkias civilizacijų analizès ypatybes. Pirma, jai būdingas tarpdisciplininis požiūris. Pasak B. Nelsono ir V. Kavolio, visos sociokultūrinès konfigūracijos ir procesai turi būti tiriami istoriniu, sociologiniu, psichologiniu ir antropologiniu požiūriu. Antra, abu autoriai pasisako už tai, kad lyginamuosiuose tyrimuose vienodas dèmesys būtų skiriamas a) visų institucinių sferų socialinėms struktūroms; b) visiems sąmonès struktūrų elementams; c) įvairaus bendrumo ir įtakingumo simbolinėms konstrukcijoms; d) sąmonès struktūrų sąveikos pokyčiams istorijos eigoje. Trečia, civilizacijų analizei empiriniais tyrimais siekiama nustatyti santykinę socialinių struktūrų, sąmonès struktūrų bei simbolinių konstrukcijų reikšmę. Ketvirta, be socialinių struktūrų, sąmonès struktūrų ir simbolinių konstrukcijų, civilizacijų analizei svarbūs ir kolektyviniai psichiniai procesai, jų mechanizmai bei kintamieji dydžiai. I konkrečių individų emocini vystymąsi atsižvelgiama tik tiek, kiek jis reprezentuoja kolektyvinius psichinius procesus. Penkta, mažesnio laipsnio sociokultūrinès konfigūracijos ir civilizaciniai procesai, kaip antai modernizacija ir racionalizacija, analizuojami susiejant juos su didžiausio masto sociokultūrinėmis konfigūracijomis bei civilizaciniais procesais.

\section{KAVOLIO CIVILIZACIJŲ STUDIJŲ METODOLOGINIAI PRINCIPAI}

Straipsnyje Civilizacinis analitinis požiūris i lyginamąsias studijas (Nelson, Kavolis 1973) išdèstytai civilizacijų tyrimų metodologijai V. Kavolis lieka ištikimas visą gyvenimą. Pažymètina, kad jo ištikimybè nèra deklaratyvi. Visiems jo civilizaciniams tyrinėjimams būdingas lyginamasis požiūris, tarpdisciplininè dvasia ir dèmesys detalei, neišleidžiant iš akių visumos. Išimtį sudaro tik lyginamieji konkrečių civilizacijų santykių ir susidūrimų tyrimai. Šiai tyrimų 
krypčiai B. Nelsonas skiria ypatingą dėmesį, o V. Kavolis jos praktiškai atsisako ir apsiriboja tik lyginamąja konkrečių institucijų ir simbolinių konstrukcijų kartu su jų socialiniu kontekstu analize. Civilizacijų sąveikos klausimą jis paliečia tik savo kultūrinei globalizacijai skirtuose straipsniuose.

Kalbant apie V. Kavolio lyginamąji požiūrị, būtina pažymèti tris dalykus. Pirma, nepaisant ištikimybès principui, kad lyginamuosiuose civilizacijų tyrimuose mažesnio laipsnio sociokultūrinès konfigūracijos ir civilizaciniai procesai būtų analizuojami susiejant juos su didžiausio masto sociokultūrinemis konfigūracijomis ir civilizaciniais procesais, V. Kavolis iš principo neatmeta ir civilizacijų kaip visumų lyginimo. Jis, kaip ir B. Nelsonas, neigiamai vertina tik toki civilizacijų kaip visumų lyginimą, kuris apsiriboja vien didžiausio masto civilizacinèmis konfigūracijomis bei procesais. Tokio tipo lyginamuosius civilizacijų tyrimus jam reprezentuoja O. Spengleris ir A. Toynbee's. Tuo tarpu V. Kavolis teigiamai vertina L. Dumonto atliktą lyginamąją Vakarų ir Indijos civilizacijų kaip visumų analizę. Kodèl? Mat lygindamas abi civilizacijas kaip visumas, L. Dumontas nestokoja dèmesio konkretiems jų elementams. Analizuoti visumas, neprarandant ryšio su konkretybėmis, jau užkoduota L. Dumonto darbo metode: „Kita vertus, antropologijai yra būdinga tai, kad dèmesys visumai čia yra neatsiejamas nuo atidumo detalei, kiekvienai smulkmenai. Kaip tik todèl buvo pasirinkta monografinè studija, leidžianti nuodugniai ịsigilinti it palyginti siauras sistemas, skrupulingai vengiant nereikalingų intarpų bei spèliojimų, nepasikliaujant išbaigtomis idejomis, perdèm parankiu žodynu, apytikrèmis reziumè, lakiais išsakymais" (Dumont 2002: 25-26). Toks darbo metodas leidžia L. Dumontui išvengti išankstinių apibendrinimų ir schematiškumo bei padaro jo Vakarų bei Indijos civilizacijų palyginimą tikslų ir konkretų.

Antra, kaip rodo lyginamųjų civilizacijų studijų istorija, lyginamasis požiūris savaime neapsaugo nuo europocentrizmo spąstų - pagundos kitas civilizacijas vertinti iš Vakarų civilizacijos perspektyvos. V. Kavolis pastebi, kad B. Nelsonui taip pat nepavyko išvengti europocentrizmo: „Ne savo bendruose pareiškimuose apie intencijas, bet faktinèse civilizacijų studijose jis buvo linkęs pasilikti vakarietiškai orientuotas. Benas Nelsonas negarbino Vakarų, ypač šiuolaikinių Vakarų, tačiau <...> jis, kartu su Maxu Weberiu, vis dar laikè juos sukūrusius vienintelę universalios reikšmès istoriją. Jis buvo linkęs žvelgti i kitas civilizacijas kaip atsakinèjančias ị vakarietiškus klausimus ir problemiškas tuo, ko joms trūko vertinant pagal Vakaru kriterijus - Indijoje universalios brolybès, Kinijoje modernaus mokslo, Islamo pasaulyje individualios sąžinès sąvokos" (Kavolis 1985: 23). Neutralios pozicijos kaip europocentrizmo įveikimo galimybe V. Kavolis netiki. Bet koks civilizacijų tyrimas jau yra civilizaciškai sąlygotas. Europocentrizmas gali būti įveiktas tik vakariečiams ir nevakariečiams tyrinètojams įsisąmoninus, kad reikšmingi lyginamųjų civilizacijų studijų klausimai gali būti keliami ir svarstomi ne tik iš Vakaru, bet ir iš kitų civilizacijų perspektyvos. Taigi pati savaime vakarietiška perspektyva nèra blogybè. Blogybe ji tampa tada, kai yra suabsoliutinama ir paverčiama vienintele galima tyrimų perspektyva.

Iš pirmo žvilgsnio gali pasirodyti, kad teigdamas įvairių civilizacinių perspektyvų galimybę V. Kavolis priartejja prie radikalaus reliatyvizmo pozicijos. Radikalus reliatyvistas teigtu, kad universali civilizacijų sociologija negalima, kad kiekviena civilizacija gali sukurti tik jai būdingą civilizacijų sociologiją. Tačiau radikalų reliatyvizmą V. Kavolis lengvai apeina pripažindamas egzistuojant universalią tyrimų metodologiją bei universalią civilizacijų organizaciją. Jo tvirtu ịsitikinimu, egzistuoja universalių sociokultūrinių elementų rinkinys, iš kurio sudaryta kiekviena konkreti istorinė civilizacija. Kaip vieną iš universalių elementų galima nurodyti liberaliąją moralinę kultūrą, kurią populiarioji sąmonè sieja išimtinai su Vakarų civilizacija. Tuo tarpu, kaip teisingai nurodo L. Donskis, šios moralinès kultūros apraiškų V. Kavolis atranda ir įvairiose nevakarietiškose civilizacijose: „Savo lyginamosiose studijose Kavolis įspūdingai kontekstuali- 
zavo kultūrinį liberalizmą, susiedamas jị su šiais praeities reiškiniais: 1) Sokrato etiniu intelektualizmu, ypač jo ideja, kad individualus protas ir sąžinė yra viršesni už kolektyvinius sprendimus; 2) kai kuriais krikščionių teologijos elementais, akcentuojančiais laisvos valios principą; 3) kinų neokonfucianistų intelektinėmis ir moralinèmis laikysenomis; 4) Japonijos Hejano epochos aristokratų kultūros mąstysena; 5) induizmo ir viduramžių Lietuvos Didžiojo Kunigaikščio Gedimino prielaida, kad visi keliai - nors ir kokie skirtingi - veda ị tą patį Dievą; 6) net ankstyvojo islamo ijtihad principu, pagal kuri kiekvienas turi teisę interpretuoti religinius islamo ịstatymus vadovaudamasis savo protu“ (Donskis 2005: 78-79). Kartu V. Kavolis nesuvienodina civilizacijų. Jos skiriasi tarpusavyje, tačiau skiriasi universalių sociokultūrinių elementų išsidèstymu bei jų ryškumu. Vieni elementai užima centrinę vietą civilizacijos organizacijoje, kiti yra labiau nustumti į periferiją. Kai kurie elementai tam tikru konkrečiu istoriniu momentu netgi gali būti išstumti iš civilizacijos organizacijos. Tačiau net ir tokiu atveju jie egzistuoja kaip slapta galimybė, kuri gali būti anksčiau ar vèliau aktualizuota.

Trečia, civilizacijų lyginimo tikslas - nustatyti, kuo skiriasi istorinès civilizacijos, o ne kas joms yra bendra. V. Kavolis rašo: „Civilizacijų analizė skiriasi nuo intelektinès ar meno istorijos tuo, jog ją simbolinès konfigūracijos domina tik tiek, kiek jos suteikia konkrečioms civilizacijoms išskirtinius bruožus ir juos - t. y. sociokultūrinị unikalumą didžiausiu empiriškai ịrodomu mastu - išreiškia“" (Kavolis 1998 a: 215).

Nurodytini dar keturi reikšmingi metodologiniai principai, kurie neminimi straipsnyje Civilizacinis analitinis požiūris ị lyginamąsias studijas (Nelson, Kavolis 1973), tačiau kuriais V. Kavolis, iš dalies ir B. Nelsonas, tiesiogiai vadovaujasi savo teoriniuose ir praktiniuose tyrinejjimuose. Pirma, pirmenybė teikiama simbolinès, o ne socialinès organizacijos analizei. Savo praktiniuose tyrinejjimuose V. Kavolis skiria dèmesio socialinei organizacijai, bet tik kaip tam tikros simbolinès konstrukcijos atsira- dimo ar funkcionavimo socialiniam kontekstui. Pati savaime socialinè organizacija jo nedomina. Tai puikiai iliustruoja straipsnis Maišto modeliai (Kavolis 1998 a), kuriame V. Kavolis analizuoja simbolinius maištingo elgesio modelius ir socialinius jų susiformavimo bei funkcionavimo kontekstus. Toks prioritetų nusistatymas yra ne savavališkas, bet teoriškai pagrịstas veiksmas. V. Kavolis vadovaujasi prielaida, kad simbolinè organizacija yra pirmesnè socialinès organizacijos atžvilgiu. Pastaroji yra simbolinès organizacijos projekcija. Todèl ji turi būti tyrinejjama tik išanalizavus simbolinę organizaciją. Būtina pastebèti, kad minètoji prielaida lemia ne tik civilizacijuc studijų organizavimą, bet pakoreguoja ir pati socialinès organizacijos analizès supratimą. Socialinę organizaciją privalu analizuoti neatsietai nuo simbolinès organizacijos. Nors V. Kavolis ne kartą pabrèžia, kad civilizacijų analizei rūpi ne tik simbolinès konfigūracijos, bet ir realios socialinès organizacijos formos, tačiau, žvelgiant i jo darbus, matyti, kad socialinès organizacijos analizè lieka neišnaudota galimybe. Visas savo jègas V. Kavolis skiria tik simbolinei organizacijai nagrinèti.

Antra, reikšmingą vietą V. Kavolio civilizacijų sociologijoje užima tipologizavimas. V. Kavolis pateikia tvarkos ir netvarkos paradigmų, energijos ir struktūros sampratų, formaliųjų konstrukcijų, moralinių kultūrų bei jų elementų, individualios tapatybės logikų, savimonès modelių, civilizacinių procesų ir socialinių judejimų tipologijas. Savo pobūdžiu išskirti tipai yra idealūs tipai. Štai tvarkos paradigmų tipus - privalomą prigimtį, spontanišką gamtą, fabriką ir meno kūrini - V. Kavolis apibūdina taip: „Šios keturios paradigmos, manyčiau, išsemia pagrindinių tvarkos vaizdinių grynuosius tipus, tačiau su dviem išlygomis: empiriniai atvejai gali daugiau ar mažiau prie jų priartèti, bet juose visada bus tam tikra priemaiša elementų, kurie į teorinị modelį netelpa; kuri nors tvarkos teorija gali apimti daugiau nei vieną pagrindinę paradigmą - joje, greičiausiai hierarchiškai, vienas tvarkos tipas gali būti laikomas apgaubiančiu ar talpinančiu, ar jam priklausančioje vietoje laikančiu kitą tvarkos tipą" 
(Kavolis 1998 b: 187). Būdami idealiais tipais V. Kavolio išskirti tipai yra euristinès priemonès, skirtos realiai ịvairių civilizacijų organizacijai ir dinamikai analizuoti.

Civilizacijų sociologijoje gana ịprasta civilizacijas apriboti vienu ar kitu tipu. Tuo tarpu, remdamasis savo bendrąa civilizacijos teorija, pagal kurią universalios konstantos yra ne tik konkretūs civilizacijos organizacijos elementai ir civilizaciniai procesai, bet ir visi jų tipai, V. Kavolis teigia, kad bet kurioje istorineje civilizacijoje ieškotina visų tipų elementų ir procesų. Tuo atveju, kai kurio nors elemento ar proceso tipo nerandama, būtina klausti, kas lèmè jo nebuvimą. Metodologiniu požiūriu toks V. Kavolio žingsnis yra vaisingas. Jis nepaprastai išplečia tyrinejjimų lauką ir leidžia dar kartą išvengti europocentrizmo spąstų.

Trečia, V. Kavolis pirmenybę teikia aprašymui, o ne priežastiniam aiškinimui, kurị civilizacijų sociologijoje plačiai taiko žymus vokiečių sociologas M. Weberis. V. Kavolis rašo: „Iš tikrųjų sociologijai dabar skubiai reikia igyti sugebejjimą adekvačiai aprašyti simbolines individualaus ir kolektyvinio patyrimo, pakankamai jautraus išreikšti nuolatos vykstančius ju pokyčius, saveikas ir konfliktus, struktūras. Tik reikiamas simbolizacijos procesu istorijoje - ir lyginamojoje perspektyvoje - supratimas gali pateikti jų paaiškinimą, - arba pasitarnauti jam kaip būtinas pagrindas" (Kavolis 1998 c: 72). Priežastinis aiškinimas V. Kavolio civilizacijų studijose pasirodo tik kartkartèmis, kaip antai analizuojant civilizacinius maištingo elgesio modelius ar nubrèžiant vieną iš moralinių kultūrų tyrimų krypčių - būtent, kokie kultūriniai ir socialiniai veiksniai turèjo ịtakos moralinès kultūros susiformavimui bei pokyčiams?

Ketvirta, išskirtini demesị V. Kavolis skiria simbolinėms konstrukcijoms, egzistuojančioms literatūroje ir mitologijoje, o ne teoriniuose normatyviniuose tekstuose. Kalbėdamas apie simbolinius savimonès modelius V. Kavolis pažymi: „Šios formos akivaizdžiausiai pasirodo literatūriniuose tekstuose, kurie aiškiai koncentruojasi ties žmogaus pastangomis aprašyti arba geriau suprasti savajji „aš“ ar savo gyvenimo apskritai reikšmę. Tokie tekstai nušviečia savojo „aš“ patirtị patikimiau už teorinius ar norminius dokumentus, formuluojančius bendrą to, koks yra arba koks turètų būti savasis „aš“, koncepciją“ (Kavolis 1998 c: 30). Pirmenybès teikimas literatūriniams ir mitologiniams tekstams aiškintinas ne tik V. Kavolio nuomone apie šių tekstų epistemologinị pranašumą teorinių normatyvinių tekstų atžvilgiu ${ }^{3}$, bet ir jo išskirtiniu demesiu kolektyviniam mąstymui, emocionalumui bei elgesiui. V. Kavolis implicitiškai remiasi prielaida, kad kolektyvines mąstymo, emocionalumo ir elgesio struktūras labiau atspindi literatūra ir mitologija, o ne teoriniai normatyviniai tekstai, kurie išreiškia elitui - mažumai - būdingas nuostatas. Ši teorinè prielaida visa jèga išsiskleidžia V. Kavolio Lietuvos kultūros tyrinèjimuose. Pavyzdžiui, analizuodamas Lietuvos kultūros modernizacijos procesus, V. Kavolis išimtinai remiasi literatūros kūriniais.

Pirmenybès teikimas literatūrai ir mitologijai, o ne teoriniams normatyviniams tekstams nėra vienintelis dalykas, siejantis V. Kavolio civilizacijų analizę su jo lituanistinèmis studijomis. Savo lituanistinèse studijose V. Kavolis nuolat naudojasi savo civilizacijų analizès metodologija. Analizuodamas lietuvių kultūrą jis remiasi ne tik konkrečiais civilizacijų analizès metodologiniais principais bei joje naudojamais metodais (pvz., autobiografijų studijų metodu), bet ir civilizacijos elementų ar procesų tipologijomis. $\mathrm{Pa}$ -

${ }^{3}$ Mintị apie epistemologinị literatūriniu ir mitologiniu tekstu išskirtinuma V. Kavolis pirma karta išsako $1979 \mathrm{~m}$. pasirodžiusiame straipsnyje „Maišto modeliai“ (Kavolis 1998 a): „Idomiau ir analitiniu požiūriu naudingiau prieiti prie blogio sąvokos pasitelkus ne apibrëžtas normatyvines formuluotes, o mitologija ir literatūrines tradicijas, kur blogis išnyra visu savo „kūnu ir krauju“ <...>. Pranašumas tas, kad bent jau istoriniu civilizaciju mitologija ir literatūra aprépia ne tik normatyvinius principus, bet ir visu pirma: 1) samones modelius, padedančius suvokti tam tikra žmogaus elgesio tipą; 2) psichologines teorijas, atskleidžiančias, kaip ir kokiomis priemonemis tam tikra kultūrine tradicija konstruoja psichologines teorijas; 3) nuorodas i sociologine sankloda, kurioje arba a) suponuojamas mite aprašytas elgesio tipas, arba b) generuojamas (arba darosi populiarus) tam tikras psichologinis jo kilmés ir apraišku paaiškinimas" (Kavolis 1998 a: 216-217). 
vyzdžiui, savo knygoje Sąmoningumo trajektorijos (Kavolis 1994) analizuodamas lietuvių moralinę istoriją nuo XVIII a. ir iki XX a. pabaigos, V. Kavolis remiasi moralinių kultūrų bei jų elementų tipologija. Egzistuoja ir atvirkštinis ryšys. Savo civilizaciniuose tyrinejjimuose V. Kavolis nevengia naudotis lietuviška medžiaga.

Savo ištakomis metodologinio literatūros tyrimų išskirtinumo ideja siekia ikicivilizaciṇ V. Kavolio kūrybos laikotarpi. Ikicivilizaciniu laikotarpiu literatūrą V. Kavolis analizuoja ne tik savo literatūros sociologijoje, bet ir kultūrinejje psichologijoje. Civilizacijų sociologijoje minètoji idèja igyja naujų niuansų. Literatūros sociologijoje ir kultūrinèje psichologijoje literatūrą V. Kavolis analizuoja kaip kolektyvinio emocionalumo išraišką, o savo konkrečiuose civilizaciniuose tyrinejjimuose ši literatūros aspektą V. Kavolis retai paliečia. Civilizacijų sociologijoje literatūra jam pirmiausiai rūpi kaip įvairiausių simbolinių modelių talpykla. Metodologinio literatūros tyrimu išskirtinumo idejja nèra vienintelis ryšys, siejantis V. Kavolio civilizacijų sociologiją su jo ikicivilizaciniu kūrybos laikotarpiu. Be pastarosios idejos, dar galima paminèti lyginamąji požiūrị ir tarpdiscipliniškumą.

Minètieji keturi metodologiniai principai kartu su straipsnyje Civilizacinis analitinis požiūris i lyginamąsias studijas išdèstytais principais sudaro bendrąji V. Kavolio civilizacijų analizès metodą. Jokie kiti V. Kavolio naudojami metodai savo bendrumo laipsniu neprilygsta šiam metodui. Kartu V. Kavolis nesivadovauja jokiais alternatyviais bendraisiais metodais ar principais. Todèl pagrịstai galima teigti, kad bendrojo metodo lygmenyje V. Kavolis nèra metodologinis anarchistas.

Tarpdisciplininiai V. Kavolio ieškojimai bene labiausiai kelia jo, kaip metodologinio anarchizmo atstovo, ịspūdị. Kurdamas tarpdiscipliniškai orientuotą civilizacijų tyrimų metodologiją, V. Kavolis atvirai neišdèsto, kokiu pagrindu remdamasis jis jungia skirtingas disciplinas - istoriją, sociologiją, psichologiją ir antropologiją bei jų viduje egzistuojančius skirtingus teorinius požiūrius ${ }^{4}$. Todèl kyla klausimas, kiek pagrịstas ispūdis, kad tarpdisciplininiuose ieškojimuose V. Kavolis elgiasi anarchistiškai?

Kad metodologinis pliuralizmas nevirstų metodologiniu anarchizmu, būtina universali kalba, kuri leistų perinterpretuoti konkrečių disciplinų ir autorių žodynus bei sujungti juos į vieną bendrą sąvokų tinklą, ir minimalus skaičius pamatinių metodologinių principų, kurie persmelktų konkrečias disciplinas ir jų viduje egzistuojančius teorinius požiūrius. Iš tikrųų V. Kavolis neišplètoja universalios metodologinès kalbos. Nepaisant to, V. Kavolio civilizacijų analizė nelieka pabiru disciplinų ir teorinių požiūrių kaleidoskopu. Jos sąryšingumą užtikrina du veiksniai. Pirmiausiai, V. Kavolio civilizacijų tyrimų metodologiją integruoja jo plètojamas civilizacijų analizès metodas. Konkrečius požiūrius ar metodus, kaip antai autobiografijų tyrimų metodą, V. Kavolis taiko derindamas juos su civilizacijų analizès metodu. Jie yra subordinuoti šiam metodui. Antra, V. Kavolio civilizacijų analizei neleidžia pažirti jos tyrimų objektas - civilizacija. Tiriant civilizaciją, būtina pasitelkti tokias disciplinas ir tokius teorinius požiūrius, kokie reikalingi išanalizuoti vieną ar kitą jos elementą ar plotmę. Žvelgiant ị V. Kavolio teorinius ir praktinius civilizacijų tyrinėjimus aiškiai matyti, kad konkrečias disciplinas ir teorinius požiūrius jis pasitelkia taip, kad šie ne konfliktuoja, bet papildo vienas kitą.

\footnotetext{
${ }^{4}$ Ta pati V. Kavolis pastebi kalbedamas apie B. Nelsono civilizaciju tyrimu metodologija: „Nelsonas kalbès apie „lyginamaja istorinę diferencinę sociokultūriniu procesu ir civilizaciniu kompleksu sociologija“" ir apie "polifoninę kultūrinès išraiškos ir patyrimo giluminę istorija ir sociologija". Kartais pokalbio metu ieškodamas būdo aiškiai pasakyti, kokiq vietą tarp akademinių disciplinu užima judèjimas (Tarptautinè lyginamuju civilizaciju studiju draugija - A. N. past.), jis išplessdavo kita pavadinima, "antroposociologija“ $i$ "psichoistorinę antroposociologiją". Pavadinimai Nelsonui buvo svarbūs, ir šie perèjimai yra raktas $\mathbf{i}$ visai jo kalbai büdinga ypatybę. Siekdamas nepaliaujamai plèsti savo pažintinio veržimosi sritị ir patraukluma, jis toliau kalbedavo apie senus dalykus vartodamas atnaujintas interpretacines kalbas. Kiekviena lingvistinè permaina atskleisdavo ar suponuodavo naujus elementus, požiūrio kampus ir galimybes. Tačiau šie pokyčiai nebuvo sistemiškai paaiškinti, retorikos pasikeitimu implikacijos retai atvirai ir smulkiai išaiškintos" (Kavolis 1985 ; 19).
} 
Išsakytą teiginị apie integruojantị tyrimų objekto pobūdị patvirtina ir V. Kavolio civilizacijų analizès, kaip bendro humanitarinių ir socialinių mokslų pagrindo, samprata. V. Kavolio požiūriu, būti bendru humanitarinių ir socialinių mokslų pagrindu civilizacijų analizei leidžia jos tyrimų objektas. Civilizacijas civilizacijų analizė analizuoja kaip didžiausio masto simbolines konfigūracijas, kurių dalinès išraiškos yra tiek konkretūs kultūrinių tradicijų kūriniai, kurie yra humanitarinių mokslų objektas, tiek ir socialinès struktūros modeliai, kurie yra socialinių mokslų objektas. Apimdamos tiek humanitarinių, tiek ir socialinių mokslų objektą, civilizacinès simbolinès konfigūracijos paverčia civilizacijų analizę pamatine disciplina. Nuo visiško inkorporavimo ị civilizacijų analizę humanitarinius ir socialinius mokslus apsaugo tik tai, kad tiek konkretūs kultūrinių tradicijų kūriniai, tiek socialinès struktūros modeliai yra ne tikslios, bet dalinès civilizacinių simbolinių konfigūracijų projekcijos.

\section{Išvados}

Atsakant ị straipsnio pradžioje suformuluotą klausimą, galima pagrịstai tvirtinti, kad Vytautas Kavolis nèra metodologinio anarchizmo atstovas. Jis nuosekliai plètoja civilizacijų tyrimų metodologiją, kurios branduolị sudaro civilizacijų analizès metodas. Šiam metodui būdingos tokios ypatybès: 1) lyginamasis požiūris; 2) tarpdiscipliniškumas; 3 ) dėmesys detalei, neišleidžiant iš akių ir visumos; 4) pirmenybès teikimas simbolinès, o ne socialinès civilizacijos organizacijos analizei; 5) tipologizavimas; 6) pirmenybès teikimas aprašymui, o ne priežastiniam aiškinimui; 6) išskirtinis dèmesys literatūrai ir mitologijai, o ne teoriniams normatyviniams tekstams.

V. Kavolio civilizacijų tyrimų metodologija yra silpniausiai integruota, plètojant tarpdisciplininị požiūrị. V. Kavolis neišplètoja universalios kalbos, kuri leistų perinterpretuoti konkrečių disciplinų ir autorių žodynus bei sujungti juos i vieną bendrą sąvokų tinklą. Vis dellto net ir šiuo atveju jo civilizacijų analizè nèra pabira atskiru disciplinų, metodų ir teorinių požiūrių sankaupa. Ją integruoja civilizacijų analizès metodas ir tyrimų objektas (civilizacija). Konkrečios disciplinos, metodai ir teoriniai požiūriai ne konkuruoja, o papildo vieni kitus.

\section{Literatūra}

Donskis, L. 2005. Tapatybe ir laisve: Trys intelektualiniai portretai. Vilnius: Versus Aureus.

Dumont, L. 2002. Ese apie individualizmą: Modernioji ideologija antropologiniu požiūriu. Vilnius: Baltos lankos.

Kavolis, V. 1985. „Nelson's Legacy of Comparative Studies" in Walter, E. V.; Kavolis, V.; Leites, E.; C. Nelson Marie (ed.) Civilizations East and West: A Memorial Volume for Benjamin Nelson. Atlantic Highlands: Humanities Press, 17-24.

Kavolis, V. 1994. Sąmoningumo trajektorijos, iš Žmogus istorijoje. Vilnius: Vaga.

Kavolis, V. 1998 a. „Maišto modeliai“, iš Kavolis, V. Civilizaciju analize. Vilnius: Baltos lankos, 215-241.

Kavolis, V. 1998 b. „Tvarkos paradigmos: gamta, fabrikas, menas", iš Kavolis, V. Civilizacijų analizè. Vilnius: Baltos lankos, 183-214.

Kavolis, V. 1998 c. „Savojo „aš“ istorijos, socialumo žemèlapiai“, iš Kavolis, V. Civilizaciju anali$z \dot{e}$. Vilnius: Baltos lankos, 29-151.

Nelson, B.; Kavolis, V. 1973. „The CivilizationAnalytical Approach to Comparative Studies", Comparative Civilizations Bulletin 5: 13-14.

Nelson, B. 1974. „De Profundis...: Responses to Friends and Critics“. Sociological Analysis 35(2): 129-142. 


\title{
VYTAUTAS KAVOLIS - A REPRESENTATIVE OF METHODOLOGICAL ANARCHISM?
}

\begin{abstract}
Alvydas Noreika
IThe paper deals with the civilization study methodology of $V$. Kavolis, a prominent Lithuanian social theoretician. A question is raised whether he is a representative of methodological anarchism. The author of the paper argues that V. Kavolis is not a proponent of methodological anarchism. V. Kavolis, civilization study methodology, despite its interdisciplinary and multimethodological nature, is quite consistent. First of all, its consistency relies on the Method of Civilization Analysis. Besides, it is coordinated by the study object - civilization. V. Kavolis uses so many disciplines, methods and theoretical approaches when analyzing any civilization element, level or process. From the standpoint of V. Kavolis, various disciplines, methods and theoretical approaches do not confront but supplement one another.
\end{abstract}

Keywords: civilization, civilization analysis, Method of Civilization Analysis, comparative approach, interdisciplinary approach.

Iteikta 2006-01-16 ; priimta 2006-02-22 